\title{
Feedback: Stock Trading Activity
}

\author{
${ }^{1}$ Denny Asmas, ${ }^{2}$ R. Adisetiawan \\ ${ }^{1,2}$ Fakultas Ekonomi Universitas Batanghari Jambi, Indonesia \\ Correspondence email: dennyasmas@unbari.ac.id, r.adisetiawan@unbari.ac.id
}

\begin{abstract}
Abstrak. Tujuan penelitian ini adalah untuk mengetahui apakah aktivitas perdagangan yang tinggi akan diikuti oleh return yang positif pada periode berikutnya, dan aktivitas perdagangan yang rendah akan diikuti oleh return yang negatif pada periode berikutnya. Hasil dari penelitian ini ditemukan bahwa aktivitas perdagangan dapat digunakan untuk memprediksikan return yang akan datang, aktivitas perdagangan yang tinggi pada perusahaan dengan nilai kapitalisasi besar dan perusahaan dengan nilai kapitalisasi kecil akan diikuti oleh return yang positif pada periode berikutnya, dan aktivitas perdagangan yang rendah pada perusahaan dengan nilai kapitalisasi besar dan perusahaan dengan nilai kapitalisasi kecil akan diikuti oleh return yang negatif pada periode berikutnya.
\end{abstract}

Kata kunci: aktivitas perdagangan, return yang positif, return yang negatif

\section{INTRODUCTION}

In the Indonesia stock exchange (idx), stocks usually dominate activity, thus rill transactions seen on the magnitude of the activity of the stock trading and stock prices. In the aggregate, the stock trading activity reflected in the total stock trading activity. Found evidence (Adisetiawan \& Surono, 2016) that individual stock trading activity of such unusual trading activity is very high during periods of daily or weekly tends to have a positive return on the Moon the next. While a very low trading activity during the period of daily or weekly tends to have a negative return in the next month. A very reasonable thing if investors demand a certain level of return over the funds diinvestasikannya. The expected return of investors from the investment made is compensation for the oppurtunity cost and risk. The expected return is the rate of return anticipated future investors. While the actual return is the rate of return that investors have been obtained in the past (Jones, 2004).

Blume et al (1994) found that commercial activity provide information in different ways. This phenomenon gives an overview of the relationship of causality between stock prices and trading activity, and when stock trading activity can affect the price of the stock, then trading activity can be used to predict the return obtained in the future. Brennan et al (1998) found that the major trading activities are likely to be followed by the expected return is low. Based on some of the views on the influence of trade transactions against a return to come, this study will test whether the trading activity can be used to predict the impending return, trading activity that very high on the company with a large capitalization value and value companies - capitalization is small will be followed by a positive return in the next period, and a very low trading activity in the company with a value of large capitalization companies and small-capitalization value will be followed by a negative return in the next period. The study was based on results of Kaniel et al (2003); Adisetiawan \& Surono (2016); Adisetiawan (2017) that test the role of commercial activity which can be used to predict the return of shares. This research aims to know that a very high commercial activity will be followed by a positive return on the next period and a very low trading activity will be followed by a negative return in the next period. There are two important reasons return in the future and trading activity, which can be useful for research of microstructure, namely: 1) gives a proposal for the use of a combination of peidagangan activity and return data in interesting conclusions drawn, whether the change of commercial activity moves the return in the future, and 2) contributed to technical analysis in reading and assess the behavior of the stock market.

\section{Predicting the Movement of Return}

The ability of commercial activity to predict changes in return can be explained on the research Adisetiawan \& Surono (2016) previously in Indonesia stock exchange, which uses the stock trading activity as a predictor of future price indicates that an increase/decrease in trading activities are likely to be followed by the increase/decrease in the index. It can be said that very little trading activity (very large) is usually 
accompanied by a decrease (increase) in price. A decrease or increase in the prices of these will be followed by a change of return obtained investors. Adisetiawan (2017) revealed that the movement of information will lead to price changes as well as changes in activity. While Wang (1994) tested the relationship between behavior of commercial activity with various investors and is associated with - price dynamics. In his model, varicosity trade conducted investor depends on the acquisition of information. When the return period of the earlier high will usually be followed by high activity in the past and will be followed by a high return in the future. Blume et al (1994), trading activity provides information in a way that is different from the information provided by the stock price. Trading activity gives the signal for investors. The observation of this phenomenon gives an overview that there is a relationship of causality between stock prices and trading activity, and when stock trading activity can affect the price of the shares then trading activity can be used to predicting the return obtained in the future.

Blume et al (1994) suggests that investors who use the infonnasi provided the stock market will provide a decision better than investors who do not use the information provided stock market. This is shown with the product a higher return for investors who are able to use the information provided stock market. Conrad et al. (1994) provide empirical evidence that a period of high return in the past will be accompanied by higher trading activity and this will be followed by a high return in the future. Conrad et al. (1994) found that high securities transactions will have an impact upon return price reversal of transactions low will correlate positively. Brennan et al (1998) found that the major trading activities are likely to be followed by the expected return is low. Chan \& Fong (2000) tested the role of the trading activities in the strategy momentum. Several theories explain that there is a relationship between commercial activity and patterns of prediction on stock return in the short term. Lee \& Swaminathan (2000) tested the usability of commercial activity in predicting return in cross sectional. The study is divided into two parts. In the first part, Lee \& Swaminathan (2000) gives the results of the existence of an interaction between the past and the return of commercial activity in the past predicts the future return to a period of observation of the medium and long term. In the second part, they found that the momentum of prices and trading activity has an important relationship. The results of the study found that trading activity in the past can be used to predict the persistence of price in the future. Geivais et al (2001) illustrates a very high commercial activity tends to have a higher return on the next period While a very low trading activity tends to have a lower return in the period the next. Kaniel et al (2003) found that trading activity to return to come almost dikeseluruhan capital markets burgeoning capital markets and new growth.

Basic investment decision consists of the expected rate of return, the level of risk, as well as the relationship between return and risk. The level of investment profits known as return. A very reasonable thing if investors demand a certain level of return over the funds that have been diinvestasikannya. The expected return of investors from the investment made is the compensation for the costs of opportunity and risk. Trading activity gives an intensity of a price movement occurs. The low level of trading activity is characteristic of investor hesitance, while commercial activity is high. occurs when there is a strong belief will rise in price. This study found evidence that trading activity will be followed by a large increase in prices. Gervais et al. (2001) found that negative abnormal trading activities will be followed by the abnormal return negative both for large companies or small companies. This research. to find evidence that the small commercial activity is usually accompanied by a decrease in prices.

\section{Hypothesis}

H1: very high trading Activity followed by a positive return in the next period.

$\mathrm{H} 2$ : very low trading Activity will be followed by a negative return in the next period

\section{METHOD}

The population which becomes the object of the research is the whole company were listed on the Indonesia stock exchange. Sampling using a purposive sampling method, i.e., sampling a specific criteria. As for the criteria used is - a) issuers listed on the Indonesia stock exchange period 2017-2018; b) issuers don't do mergers, delisting is, partial liquidation, or seasoned equity offering during trading interval; c) Stock shares of less than one year of trading on trading interval is not included in the sample; d) stocks have a record trade during the period of observation. This research uses data of commercial activity and the return 
of shares all shares listed on the Indonesia stock exchange. Trade will be eliminated one day interval between trading interval Model used to calculate the cumulative stock trading return interval can be used the following equation:

$R_{i j t}=\sum_{t-1}^{t}\left(1+r_{i j t}\right)-1$

Description: $=R_{i j t}=$ return cumulative stock

Where to calculate cumulative average return of stocks daily while high volume or low volume trading on the overall intervals can be done with:

1. The average cumulative return on an event high used the equation:

$$
\overline{R^{h}}=\frac{\sum_{i=1}^{n} \sum_{j=1}^{M_{i j}^{h}} R_{i j}^{h}}{\sum_{i=j}^{n} M_{i}^{h}}
$$

Description: $\overline{R^{h}}=$ average cumulative return to trading volume high volume; $i=\operatorname{trading}$ interval; $j=1$, $\ldots, M_{i}^{h}=$ high volume on trading $i$.

2. The average cumulative return at a time when low volume equations:

$$
\overline{R^{l}}=\frac{\sum_{i=1}^{n} \sum_{j=1}^{M_{i}^{I}} R_{i j}^{I}}{\sum_{i=j}^{n} M_{i}^{I}}
$$

Description: $\overline{R^{h}}=$ average cumulative return to trading volume low volume; $i=$ trading interval; $j=1$, $\ldots, M_{i}^{h}=$ low volume on trading $i$.

Impending return is calculated with the average return for high volume or low volume trading at the interval, with the following equation:

$$
N R=\frac{\sum_{i=1}^{n}\left[\sum_{j=1}^{M_{i}^{h}} R_{i j}^{h}+\sum^{M_{i j}^{l}} R_{i j}^{I}\right]}{\sum_{i=1}^{n}\left[\left[M_{i}^{h}+M_{i}^{l}\right]\right.}
$$

Description: $N R=$ Net Return; $M_{i}^{h}=$ Volume of transactions at the time high trading volumes on the interval to the $i ; M_{i}^{l}=$ Volume of transactions at the time of low trading volumes on the interval to $i$.

Trading activity was measured by the number of shares traded. Trading activity was used to identify stocks that have abnormal trading activity during the interval. Stock trading activities will be classified into high, normal, and low. Measurement of daily activity was measured by using the value of shares traded on the day. If the trading activities during the period of formation are at a level of $20 \%$ of the top (bottom) of the overall daily activity, then those stocks categorized as high activity (low). Determination of the level of this trade activity with the basic research done Kaniel et al (2003) stating that this level is relevant to be applied to a number of emerging capital markets. Thus, the volume of transactions on the ranking of the top $20 \%$ will be categorized as high volume and the lowest $20 \%$ will be categorized as low volume. To see if trading activity can be used to predict the coming return can be done by testing the regression equation as follows:

$F R_{i j n}=\beta_{0}+\beta_{1}$ TRADVOL $+\beta_{2}$ DPENG $+\varepsilon_{i j}$

$F R_{i j n}=$ Return to come during the day observations; DPENG = Dummy Announcements; $\beta_{0}=$ Intercept; $\beta_{1}, \beta_{2}=$ coefficient of regression; $\varepsilon_{i j}=$ error term.

While the influence of activity (high volume and low volume) against return to come in companies with large capitalizations and value companies with small capitalization value can be done testing with the regression equation as follows:

$R_{i j n}=\beta_{0}+\beta_{1}$ HIGHVOL $+\beta_{2}$ LOWVOL $+\varepsilon_{i j}$

$R_{i j n}=$ Return to come during the day observations; HIGHVOL = volume in formation period are categorized as high volume; LOWVOL $=$ volume in formation period categorized low volume; $\beta_{0}=$ Intercept; $\beta_{1}, \beta_{2}=$ coefficient of regression; $\varepsilon_{i j}=$ error term

\section{RESULTS}

The sample in this study consists of over 389 stocks classified into 27 trading interval (for a 5-day observation) and 54 trading interval (for a 10-day observation). Each trading interval will be classified into 2 
portfolio based on market capitalisation, namely small firms and large firms. Very high trading activity followed by a positive return on the next period can be seen in table 1 . Hypothesis test results can be seen the value of their significance of variables lnHigh (on small capitalization value issuers) of 0.041 and $\ln H i g h$ (in the large capitalization value issuers) by 0.020 with positive direction (for a period of 5 days observation). The same thing was found on a 10-day observation period that indicates their significance of variables lnHigh (on small capitalization value issuers) of 0.044 and lnHigh (in the large capitalization value issuers) amounted to 0.023 with positive direction. This means a high trading activity will be followed by a positive return for the next period. This is consistent with that done Gervais et al (2001) and Kaniel et al (2003). Gervais et al. (2001) found that the negative trading activities will be followed by a abnormal return is negative. It is stated in the hypothesis 2 stating that a very low trading activity will be followed by a negative return in the next period.

The results of hypothesis testing on a 5-day observation found that the value of the variable lnlow their significance on the issuer-the issuer with small capitalization value of 0.014 and the value of the variable lnLow in signilikansinya issuers-issuers by capitalization value big negative in the direction of 0.000 . As for the 10-day observation. The results of hypothesis testing on a 5-day observation found that the value of the variable lnlow their significance on the issuer-the issuer with small capitalization value of 0.036 their significance and value of the variable lnlow on issuer-the issuer with the value of the capitalization big of a negative 0.018 with directions. This means a very low trading activity will be followed by a negative return for the next period. So the hypothesis 2 is acceptable. This is consistent with that done Gervais et al (2001) and Kaniel et al (2003) who found that the negative trading activities will be followed by a return change will come.

lmplikasi that can be given to investors and analysts pasai capital that high trading activity will be followed by a positive return on the next period and this is true vice versa. So investors and capital market analysts can make the information contained in the activity in analyzing and assessing the company's upcoming return.

Table 1

The results of hypothesis testing the influence of Stock Trading Activity Against Return to come Panel A: Small Firms

\begin{tabular}{l|c|c|c|c|c|c}
\hline & \multicolumn{2}{c}{ 5-day Observation period } & \multicolumn{2}{c}{ 10-day Observation period } \\
\hline Variable & Sig. & Direction & Description & Sig. & Direction & Description \\
\hline InLow & 0,014 & Negative & Significant & 0,036 & Negative & Significant \\
& $(-2,777)$ & & & $(-2,456)$ & & \\
InHigh & 0,041 & Positive & Significant & 0,044 & Positive & Significant \\
& $(3,346)$ & & & $(3,313)$ & & \\
\hline
\end{tabular}

Panel B: Large Firms

\begin{tabular}{l|c|c|c|c|c|c}
\hline & \multicolumn{3}{c}{ 5-day Observation period } & \multicolumn{3}{c}{ 10-day Observation period } \\
\hline Variable & Sig. & Direction & Description & Sig. & Direction & Description \\
\hline InLow & 0,000 & Negative & Significant & 0,018 & Negative & Significant \\
& $(-4,657)$ & & & $(-3,869)$ & & \\
InHigh & 0,020 & Positive & Significant & 0,023 & Positive & Significant \\
& $(2,146)$ & & & $(3,658)$ & & \\
\hline
\end{tabular}

Source: processed data

\section{REFERENCES}

Adisetiawan, R., and Yunan Surono, 2016, Indonesia Capital Market Efficiency, British Journal of Economics, Finance and Management Sciences, 11(1), 108-121

Adisetiawan, R., 2017, Does Stock Option Force Bid-Ask Spread and Abnormal Return?, International Research Journal of Finance and Economics, (161), 96-104

Blume, L., Easley, D and O'hara, M. 1994. Market Statistics and Technical Analysis: The Role of Volume, The Journal of Finance, 49(1), 153-181. 
Brennan, Michael J., Choedia, Tarun., Subrahmanyam, A., 1998, Alternative Factor Specification, Security Characteristics, and The Cross Section of Expected Returns. Journal of Financial Economics, 345373

Conrad, J.S., Hameed, A, and Niden, C. 1994. Volume and Autocovariances in Short Horizon Individual Security Returns. The Journal of Finance, 49(4), 1305-1329

Chan, K, and Fong, W., 2000. Trade Size, Order-limbalance, and the Volatility Volume Relation. Journal of Financial Economics. 57, 247-273

Gervais, S., Kaniel, R., and Mingelgrin, D.H., 2001, The High-Volume Return Premium, The Journal of Finance, 56(3), 877-919

Jones, Charles P. 2004. Investment Analysis and Management, 9 edition. John Wiley \& Sonc Inc. New York.

Kaniel, Ron., Dong Li, dan Laura Starks, 2003, The High Volume Return Premium and lnvestor Recognition Hypothesis: International Evidence and Determinants, Working Paper, University of Texas

Lee, Charles, M.C., and Swaminathan, Bhaskaran., 2000, Price Momentum and Trading Volume, The Journal of Finance, 55(5), 2017-2069

Wang, Jiang., 1994. A Model of Competitive Stock Tracling Volume, Journal of Political Economy, 102, 127-168. 